\title{
Smoking behaviour and patterns among university students during the Syrian crisis
}

Amr Idris ${ }^{1}$, Tareq Al Saadi², Tarek Turk ${ }^{2}$, Mahmoud Alkhatib ${ }^{2}$, Mohammed Zakaria $^{1}$, Bisher Sawaf $^{1}$ and Basel Edris ${ }^{2}$

${ }^{1}$ Department of Internal Medicine, Faculty of Medicine, Syrian Private University, Damascus, Syrian Arab Republic (Correspondence to: A. Idris: amridris@hotmail.com). ${ }^{2}$ Department of Internal Medicine, Faculty of Medicine, Damascus University, Damascus, Syrian Arab Republic.

\begin{abstract}
Background: The ongoing Syrian war has resulted in many changes in the social and economic life of Syrians. To date, no study has documented the relationship between smoking behaviour and the war.

Aim: To determine the prevalence of cigarette smoking among university students during the crisis in Damascus, Syrian Arab Republic, and the impact of the war on smoking behaviour.

Methods: We conducted an anonymous online cross-sectional survey of 1027 undergraduate students from all years and colleges at Damascus University.

Results: The overall prevalence of tobacco smoking was $24.73 \%$ for cigarettes and $30.4 \%$ for waterpipe. Prevalence of cigarette smoking was significantly higher in men, non-health profession students, and in students living away from their families. There was no significant difference in prevalence of smoking cigarettes when comparing students according to their origin (urban vs rural), year of study, and change of residence due to war. War was associated with a significant increase in mean number of cigarettes smoked daily, and 53.1\% of smokers reported that the number of cigarettes consumed per day had increased since the beginning of the war.
\end{abstract}

Conclusions: Increased smoking is an additional health concern in areas of conflict and may require special consideration and efforts by public health authorities.

Keywords: Syria, civil war, students, smoking, tobacco

Citation: Idris A; Al Saadi T; Turk T; Alkhatib M; Zakariah M; Sawaf B; et al. Smoking behaviour and patterns among university students during the Syrian crisis. East Mediterr Health J. 24;2018(2):154-160. https://doi.org/10.26719/2018.24.2.154.

Received: 10/08/15; accepted: 01/03/17

Copyright (C) World Health Organization (WHO) 2018. Some rights reserved. This work is available under the CC BY-NC-SA 3.oIGO license (https:// creativecommons.org/licenses/by-nc-sa/3.o/igo).

\section{Introduction}

Tobacco is the only legal drug that kills many of its users when used exactly as intended (1). The World Health Organization (WHO) has estimated that tobacco use (smoking and not smoking) is currently responsible for the death of $\sim 6$ million people worldwide each year (1).

A previous study in 2004 investigating tobacco use among university students in the Syrian Arab Republic showed worrying trends, with $23 \%$ of students smoking cigarettes and $15 \%$ smoking waterpipes (2). In 2008 , investigations of cigarette and waterpipe smoking among Syrian medical students showed that the overall prevalence of tobacco smoking was $10.9 \%$ for cigarettes, $23.5 \%$ for waterpipe and $7.3 \%$ for both (3).

Since the beginning of the Syrian war in 2011, the Syrian Arab Republic has experienced a decline in national standards of living and steep rises in the prices of commodities, as well as many changes in the social and economic lives of Syrians (4). By July 2013, the Syrian economy had shrunk by $45 \%$ since the start of the conflict; unemployment increased fivefold; the value of the currency decreased to a 6th of its prewar value; and the public sector lost US\$15 billion $(4,5)$. As of late of 2014, around $60 \%$ of Syrians are jobless and around the same proportion live in extreme poverty, meaning that they cannot afford the basics that they need to stay alive or support their household, according to a United Nations backed report (6). Today, the median Syrian salary is < 16000 Syrian pounds per month (7) (approximately US\$ 64). It is estimated that out of the 10.8 million Syrians affected by the conflict, $\sim 6.5$ million have been displaced (8). Education is in a state of collapse with $50.8 \%$ of all school-age children no longer attending school during 2014-2015. Furthermore, almost half of all children in Syria are 3 years behind where they are expected to be in standard grade objectives (6). These dramatic changes may combine to affect smoking habits among Syrians.

In 2012, noncommunicable diseases (NCDs) were the leading cause of death worldwide (9). Patients with NCDs in low- and middle-income countries have rapid disease progression (10), therefore, the impact of NCDs is particularly severe in these countries (9). However, governments of low- and middle-income countries fail to keep pace with the growing demands for prevention of NCDs (10). Tobacco is one of the four most common modifiable risk factors for NCDs (10). The role of tobacco in NCDs highlights the importance of investigating its consumption, especially in a low-income, war-torn country like the Syrian Arab Republic.

In this study, we aimed to determine the prevalence of 
cigarette smoking among university students during the crisis in Damascus, Syrian Arab Republic, and the impact of the war on smoking behaviour. We also investigated students' knowledge and awareness of the risks of smoking.

\section{Methods}

\section{Study design}

We conducted an online cross-sectional survey at Damascus University on 31 May 2015 during the WHO "World No Tobacco Day". The survey was directed only at undergraduate students. Accordingly, 2000 undergraduate students from all years and colleges were randomly selected from the university students' lists, and invited to participate in the online survey via Google Forms after they logged into their personal email to ensure no repeated results were generated. The total number of responses was 1057 with a response rate of $52.85 \%$; 30 of these responses were incomplete and were excluded.

The questionnaire was written in Arabic and consisted of 17 questions about the demographic and academic details of the participants; their smoking behaviour before and after the beginning of the Syrian war; family and peer smoking behaviour; and personal attitudes and beliefs about smoking and quitting. The questionnaire was designed by the authors after reviewing the related medical literature and was not piloted or validated locally. Questions were in multiple choice format. We added an "others" option, with a space to provide participants' unique answers to questions that investigated reasons for starting, quitting or not trying smoking.

\section{Definitions}

Smoking status was established in accordance with the criteria for cigarette smoking used in the US Centers for Disease Control and Prevention (CDC) Morbidity and Mortality Weekly Report. (11). The criteria defined a current smoker as a person who had smoked $\geq 100$ cigarettes during their lifetime and was currently smoking. A former smoker was defined as a person who had smoked $\geq 100$ cigarettes during their lifetime but reported quitting smoking. Individuals who reported smoking $<100$ cigarettes during their lifetime or having never smoked were categorized as nonsmokers. Those who were defined as former smokers or nonsmokers were classified as currently nonsmokers.

For waterpipe smoking, participants were asked if they smoked a waterpipe as a regular habit. Characteristics of use pattern, such as frequency, were considered to be out of scope for this study and were not assessed.

Students studying medicine, dentistry or pharmacy were categorized as health profession students. Students from other faculties were categorized as non-health profession students.

\section{Ethical issues}

Before distributing the questionnaire, the objectives of the study were explained to the participants, and they were informed that their participation was voluntary, and anonymity was assured. Ethical approval of the study was obtained from the Ethics Committee, Faculty of Medicine, Damascus University.

\section{Statistical analysis}

Participants' characteristics were reported as frequencies and percentages (for categorical variables) or means and standard deviations (SDs) (for continuous variables). To investigate the statistical significance of the differences in participants' characteristics between current cigarette smokers and current nonsmokers, we used the $\chi^{2}$ test (for categorical variables) or $t$ test (for continuous variables). $P<0.05$ was the level of statistical significance in all statistical tests. Risks were reported as odds ratio (OR) with $95 \%$ confidence interval (CI). All statistical analyses were carried out using SPSS version 20.0 (SPSS, Chicago, IL, USA).

\section{Results}

\section{Participants' characteristics and smoking prevalence}

Participants' characteristics are reported in Table 1. The study sample consisted of 575 men (55.9\%) and 452 women (44.1\%), with an overall mean age (SD) of 21.55 (2.04) years (range 18-26 years). The overall prevalence of current tobacco smoking was $24.73 \%$ for cigarettes (39.82\% male, $5.54 \%$ female), and $30.4 \%$ for waterpipe (33.2\% male, $26.8 \%$ female). Overall prevalence of former cigarette smokers was $4.47 \%$ ( $7.3 \%$ male, $0.88 \%$ female). Mean age for current smokers and current nonsmokers was 21.98 (1.92) and 21.34 (2.06) years, respectively. Prevalence of cigarette smoking was significantly higher in male compared to female students (39.82\% and 5.54\% respectively; $P<0.001$ ); in nonhealth profession compared to health profession students (31.26\% and $18.56 \%$ respectively; $P<0.001$ ); and in students living away from their families compared to those living with their families $(42.34 \%$ and $20.58 \%$ respectively; $P<$ $0.0001)$. There was no significant difference in prevalence of smoking cigarettes between those from rural or urban areas $(24.4 \%$ and $24.9 \%$ respectively; $P=0.87)$. There was no significant difference between those in their 1st, 2nd or advanced (3rd or more) year of study regarding being current smokers $(P=0.19)$, or between those who changed their residence due to war and those who did not $(P=0.26)$. Mean number of close friends who were currently smoking cigarettes was significantly higher in current smokers compared to nonsmokers (3.19 and 1.75 respectively; $P<0.001)$. Mean number of household members who were currently smoking cigarettes was significantly higher in current smokers compared to nonsmokers (1.73 and 1.49 respectively; $P=0.015$ ). 


\begin{tabular}{|c|c|c|c|c|}
\hline & $n=1027$ & $\begin{array}{l}\text { Current cigarette } \\
\text { smokers }(n=254)\end{array}$ & $\begin{array}{c}\text { Current cigarette } \\
\text { nonsmokers }(n=773)\end{array}$ & $p^{a}$ \\
\hline Age: mean (SD), yr & $21.55(2.04)$ & $21.98(1.92)$ & $21.34(2.06)$ & $<0.001^{*}$ \\
\hline \multicolumn{5}{|l|}{ Gender, $\mathbf{n}(\%)$} \\
\hline Male & $575(55.9 \%)$ & $229(39.82 \%)$ & $346(60.17 \%)$ & \multirow{2}{*}{$<0.001^{*}$} \\
\hline Female & $452(44.1 \%)$ & $25(5.54 \%)$ & $427(94.46 \%)$ & \\
\hline \multicolumn{5}{|l|}{ Field of study, $n$ (\%) } \\
\hline Health professions students & $528(51.4 \%)$ & $98(18.56 \%)$ & $430(81.43 \%)$ & \multirow{2}{*}{$<0.001^{*}$} \\
\hline Non-health professions students & $499(48.6 \%)$ & $156(31.26 \%)$ & $343(68.73 \%)$ & \\
\hline \multicolumn{5}{|l|}{ Year of study, $n(\%)$} \\
\hline 1st & $108(10.5 \%)$ & $19(17.59 \%)$ & $89(82.4 \%)$ & \multirow{3}{*}{0.19} \\
\hline 2nd & $268(26.1 \%)$ & $68(25.37 \%)$ & $200(74.62 \%)$ & \\
\hline Advanced ( $\geq 3$ rd) & $651(63.4 \%)$ & $167(25.6 \%)$ & $484(74.34 \%)$ & \\
\hline \multicolumn{5}{|l|}{ Living status, $n(\%)$} \\
\hline Away from family & $196(19.1 \%)$ & $83(42.34 \%)$ & $113(57.65 \%)$ & \multirow{2}{*}{$<0.001^{*}$} \\
\hline With family & $831(80.9 \%)$ & $171(20.58 \%)$ & $660(79.42 \%)$ & \\
\hline \multicolumn{5}{|l|}{ Origin, $\mathbf{n}(\%)$} \\
\hline Urban & $699(68.1 \%)$ & $174(24.9 \%)$ & $525(75.1 \%)$ & \multirow{2}{*}{0.87} \\
\hline Rural & $328(31.9 \%)$ & $80(24.4 \%)$ & $248(75.6 \%)$ & \\
\hline \multicolumn{5}{|c|}{ Change of residence after beginning of war, $n(\%)$} \\
\hline Yes & $374(36.4 \%)$ & $100(26.7 \%)$ & $274(73.3 \%)$ & \multirow{2}{*}{0.26} \\
\hline No & $653(63.6 \%)$ & $154(23.6 \%)$ & $499(76.4 \%)$ & \\
\hline $\begin{array}{l}\text { No. of close friends smoking } \\
\text { cigarettes, mean (SD) }\end{array}$ & $2.11(1.65)$ & $3.19(1.06)$ & $1.75(1.65)$ & $<0.001^{*}$ \\
\hline $\begin{array}{l}\text { No. of household members } \\
\text { smoking cigarettes, mean (SD) }\end{array}$ & $1.55(1.36)$ & $1.73(1.42)$ & $1.49(1.33)$ & $0.015^{*}$ \\
\hline \multicolumn{5}{|l|}{ Waterpipe smoking, $\mathbf{n}(\%)$} \\
\hline Yes & $312(30.4 \%)$ & $135(43.3 \%)$ & $177(56.7 \%)$ & \multirow{2}{*}{$<0.001^{*}$} \\
\hline No & $715(69.6 \%)$ & $119(16.6 \%)$ & $596(83.4 \%)$ & \\
\hline
\end{tabular}

*Significant at the level of 0.05 .

${ }^{a}$ Comparing participants' characteristics according to their current smoking status.

$S D=$ standard deviation .

\section{Characteristics and smoking pattern of current cigarettes smokers}

Data about smoking patterns of current smokers before and after the beginning of the Syrian war are shown in Table 2. The results indicate a possible negative effect of the war on smoking behaviour. Mean reported number of daily cigarettes smoked increased significantly from 8.84 (7.91) before to 14.83 (7.13) $(P<000.1)$. One hundred and thirty-five smokers $(53.1 \%)$ reported that the number of cigarettes smoked per day had increased since the beginning of the war, while $105(41.4 \%)$ reported no change and only $14(5.5 \%)$ reported a decrease in their cigarette consumption. After the beginning of the war, 88 current smokers (34.7\%) reported a monthly cost of cigarette smoking of 3000-5000 Syrian pounds. Only 33 smokers (13\%) reported a monthly cost of 1000-3000 Syrian pounds. The most common reported reasons for smokers to continue smoking were being addicted to smoking and habit (33.5\% of smokers), and personal life distress ( $20.9 \%$ of smokers). The least reported reason was the influence of friends ( $2 \%$ of smokers).

\section{Main reasons for starting, quitting and not trying smolking}

The reasons that made current and former smokers start smoking was to handle stress (38\%), followed by friends' influence $(29.6 \%)$, trying a new experience $(25.6 \%)$, the Syrian war (3.6\%) and finally influence of family (3\%). The reasons to quit smoking were personal health concerns $(71.73 \%)$, increased cost $(17.4 \%)$, family concern $(4.3 \%)$ and other reasons not listed in the survey (6.5\%). Health concerns $(73.7 \%)$ and religious beliefs $(23.2 \%)$ were the two main reasons for not trying to smoke among those who had never smoked, followed by financial concerns (1.3\%), work $(1 \%)$ and other reasons not listed in the survey $(0.7 \%)$.

\section{Students' knowledge about cigarette smoking and awareness about risks of smoking}

More than two thirds of all participants agreed with 


\begin{tabular}{lc}
\hline Table 2 Characteristics and smoking pattern of current cigarettes smokers (n = 254) & $8.84(7.91)$ \\
No. of daily cigarettes smoked before the war, mean (SD) & $14.83(7.13)$ \\
No. of daily cigarettes smoked after beginning of war, mean (SD) & $135(53.1 \%)$ \\
Changes in smoking habits after beginning of war, $\mathbf{n}(\%)$ & $14(5.5 \%)$ \\
Increased & $105(41.4 \%)$ \\
Decreased & $74(29.1 \%)$ \\
Same & $33(13 \%)$ \\
Monthly costs of cigarettes smoked after beginning of war (SP), $\mathbf{n}(\%)$ & $88(34.7 \%)$ \\
$<1000$ & $59(23.2 \%)$ \\
$1000-3000$ & $53(20.9 \%)$ \\
$3000-5000$ & $41(16.1 \%)$ \\
$>$ 5000 & $5(2 \%)$ \\
Main reason to continue smoking, $\mathbf{n}(\%)$ & $85(33.5 \%)$ \\
Personal life distress & $12(4.7 \%)$ \\
Lack of willpower to quit & $58(22.8 \%)$ \\
Friends & \\
Addiction/habit & \\
Stressors related to the Syrian war & \\
Others &
\end{tabular}

$S D=$ standard deviation; SP, Syrian pound.

statements about some harmful aspects of smoking (Table 3). However, a smaller percentage of current smokers agreed with those statements compared to current nonsmokers, indicating lower knowledge and awareness about risks of smoking among current smokers.

\section{Discussion}

Understanding prevalence and factors associated with cigarette smoking among students is a major public health concern in developing countries. Because of the delayed health effects of smoking, morbidity and mortality attributable to smoking in developing countries have not yet surpassed those in developed countries but are likely to do so in the near future $(12,13)$. Our study revealed that current smoking prevalence (39.82\% male; $5.54 \%$ female; $24.73 \%$ overall) was high compared to that reported among Syrian students in 2004 (30.9\% male; $7.5 \%$ female) (2) and 2008 (15.8\% male; 3.3\% female; 10.9\% overall) (3) before the beginning of the Syrian war. However, it remained close to the prevalence in neighbouring countries such as Lebanon (26.3\%) (14) and Jordan (50.2\% male; 6.5\% female; $28.6 \%$ overall) (15). Comparing smoking prevalence across these studies might be limited by the fact that each study adopted a different smoking status definition, which may partially explain the differences in prevalence.

There were important gender differences in tobacco smoking habits. Prevalence of cigarette smoking was significantly higher in men compared to women. Jarallah et al. (16) reported that significantly more men than women smoke in Arab countries because of social stigma against women smoking, which is seen as shameful behaviour. Mean ages for current cigarette smokers and current nonsmokers were 21.98 and 21.34 years, respectively. Moreover, there was no significant difference in smoking prevalence between 1st, 2nd or advanced year (3rd or more) students, indicating that all students are subject to the factors that can lead to increased cigarette consumption, regardless of their age and study stage.

Monthly cost of cigarette smoking after the beginning of the war varied among participants, potentially due to differences in the number and brand of cigarettes that they consumed. Although the monthly costs seem small when converted to US dollars, they are considered relatively large expenses in the context of Syrians' incomes. The price of tobacco products also varies widely based on the origin (locally manufactured or imported) and brand. In addition, the study showed less awareness about the deleterious effects of smoking among smokers when compared to nonsmokers. This difference may be reflected by the significantly lower prevalence of cigarette smoking among students of health professions compared to those attending other study programmes. Due to the deterioration in health and education and the scarcity of health awareness campaigns in the Syrian Arab Republic, which is a developing country, the public are expected to have limited knowledge about the risks of smoking. This lack of awareness may contribute to increased prevalence of smoking, simply because people do not know how smoking can be harmful to them.

The study reveals a potential negative effect of the war on students' smoking habits: more than half of smokers reported an increase in the number of cigarettes consumed per day, and the mean number of cigarettes smoked daily has almost doubled since the beginning of the war. Data about increased cigarette consumption after the beginning of the war are subjective and 


\begin{tabular}{|c|c|c|c|c|}
\hline Statement & Total $(n=1027)$ & $\begin{array}{l}\text { Current cigarette } \\
\text { smokers }(n=254)\end{array}$ & $\begin{array}{l}\text { Current non- } \\
\text { smokers }(n=773)\end{array}$ & $P^{a}$ \\
\hline $\begin{array}{l}\text { Rates of lung cancer significantly higher in all smokers } \\
\text { compared to nonsmokers. }\end{array}$ & $690(67.2 \%)$ & $148(58.3 \%)$ & $542(70.2 \%)$ & $<0.001^{*}$ \\
\hline $\begin{array}{l}\text { Smokers are more exposed to heart and cardiovascular } \\
\text { diseases than nonsmokers are }\end{array}$ & $783(76.2 \%)$ & $175(68.9 \%)$ & $608(78.65 \%)$ & $0.002^{*}$ \\
\hline Smoking during pregnancy is harmful to the baby & $737(71.7 \%)$ & $147(57.9 \%)$ & $590(76.3 \%)$ & $<0.001^{*}$ \\
\hline Passive smoking is harmful to nonsmokers & $711(69.2 \%)$ & $109(42.9 \%)$ & $602(77.87 \%)$ & $<0.001^{*}$ \\
\hline Smoking is an addiction & $681(66.3 \%)$ & $160(63 \%)$ & $521(67.4 \%)$ & 0.197 \\
\hline
\end{tabular}

Data are presented as $n(\%)$ for those who agree to the corresponding statement.

*Significant at the level of 0.05 .

${ }^{a}$ Comparing participants' agreement to each corresponding statement according to their current smoking status.

only express the participants' own perspectives and experiences. An objective, less-biased method, should be used in future studies to verify the negative effect of the war on smoking among Syrian students.

With regard to the law, a presidential decree to ban smoking in public spaces came into effect in 2010 (17). Few data exist about the effectiveness of antismoking legislation in the Syrian Arab Republic. A report from the WHO (18) showed that many of the data about antismoking measures were not available. The antismoking measures that were reported included taxation of cigarettes (58\% of retail price is tax), bans on tobacco advertising on television and radio and internet, in magazines and newspapers, and bans on tobacco promotion and sponsorship. However, there is no evidence of the proper application of these laws during the war. Increased chaos, absence of government authority in many parts of the Syrian Arab Republic, and war-caused deterioration in all aspects of life suggest a limited application of such laws.

Smokers had to assess and remember their smoking consumption before and after the beginning of the war, so recall bias was one of the major limitations in this study. Another major limiting factor was the use of a nonpiloted, nonvalidated questionnaire. In addition, the relationship between smoking and war may have been subject to cofounding factors. The conduct of such research in a disturbed atmosphere, as in the Syrian Arab Republic during the ongoing crisis, imposed some challenges such as funding for research and meeting some students who were hesitant to participate, possibly concerned about privacy and safety. This was of course in addition to the unsafe environment caused by the ongoing war. We managed to overcome such challenges by collaborative teamwork, and by discussing with the participants the aims and importance of the research.

Overall, we believe that the suggested increase in tobacco consumption can be attributed to the increased life stressors during the war, lack of application and maintenance of antismoking laws, and the decrease in antismoking campaigns that may have led to decreased public awareness about the negative effects of tobacco. In the light of these results, we urge policy makers in the Syrian Arab Republic to ensure more public education about the harm of smoking, and ensure application of relevant legislation to address the potential increase in smoking rates among Syrian students. We also recommend that volunteer teams in the Syrian Arab Republic, the healthcare community and media professionals make more efforts to raise awareness about the risks of smoking. Universities and schools can play a role in increasing awareness of the harm of smoking and facilitating tobacco cessation programmes for students.

In conclusion, the Syrian war is associated with increased tobacco consumption among university students. This will aggravate the long-term negative effects of the war upon civilians, and impose an additional challenge for health organizations. We recommend increasing efforts towards education about smoking in the community and among students who are currently living in conflict areas, as students play an important role in the spread of knowledge and raising awareness in their communities.

Funding: None.

Competing interests: None declared.

\section{Comportements et schémas tabagiques parmi les étudiants à l'université durant la crise syrienne}

\section{Résumé}

Contexte : La guerre qui sévit en République arabe syrienne a conduit à de nombreuses modifications dans la vie sociale et économique des Syriens. À ce jour, aucune étude ne documente la relation entre les comportements tabagiques et la guerre. 
Objectif : Déterminer la prévalence de la consommation de cigarettes parmi les étudiants à l'université pendant la crise à Damas, en République arabe syrienne, et l'impact de la guerre sur les comportements tabagiques.

Méthodes : Nous avons organisé une enquête en ligne transversale et anonyme sur 1027 étudiants de premier cycle de toutes les années et dans toutes les facultés de l'Université de Damas.

Résultats : La prévalence globale du tabagisme était de $24,73 \%$ pour la cigarette, et de $30,4 \%$ pour la pipe à eau. La prévalence de la consommation de cigarettes était significativement plus élevée chez les hommes, les étudiants d'autres filières que celle de la santé, et chez les étudiants ne vivant plus dans leurs familles. Aucune différence significative n'a été observée pour la prévalence de la consommation de cigarettes en fonction de l'origine des étudiants (urbaine ou rurale), de leur année d'étude, ou de leur changement de résidence du fait de la guerre. La guerre était associée à une augmentation significative du nombre moyen de cigarettes consommées quotidiennement, et $53,1 \%$ des fumeurs rapportaient que le nombre de cigarettes qu'ils consommaient par jour avait augmenté depuis le début de la guerre.

Conclusions : L'augmentation du tabagisme est une préoccupation sanitaire supplémentaire dans les zones de conflit, et requiert une attention spéciale ainsi que des actions de la part des autorités de santé publique.

$$
\text { سلوك الخلاصة إدريس، طارق السعدين وأنهاطه في صفوف الطلاب الجامعيين خلال الأزمة السورية محمود الخطيب، محد زكريا، بشر صواف، باسل إدريس }
$$

الخلفية: أسفرت الحرب الدائرة في سوريا عن كثير من التغييرات في الحياة الاجتماعية والاقتصادية للسوريين. ولم توثقّ، حتى تاريخه، أي دراسة

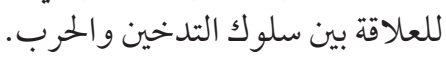

الهدف: تحديد مدى انتشار تدخين السجائر بين الطلاب الجامعيين خلال الأزمة في دمشق، الجمهورية العربية السورية ، وأثر الحرب على سلوك التدخين.

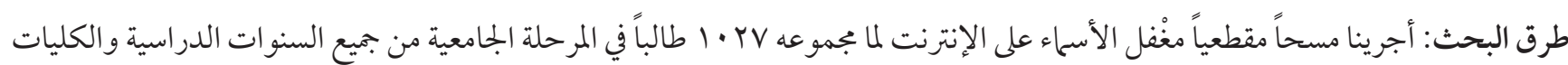
في جامعة دمشق.

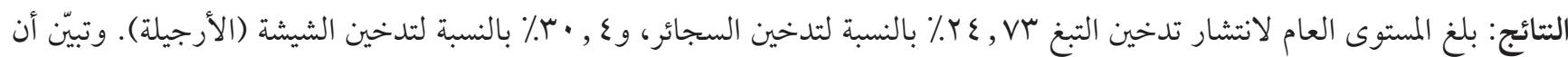

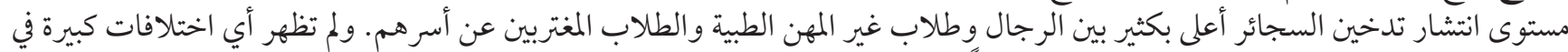

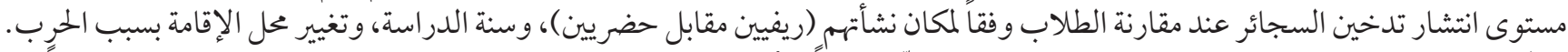

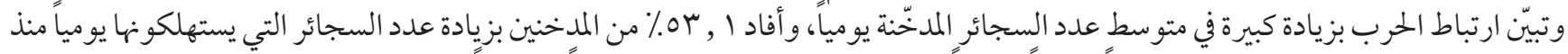

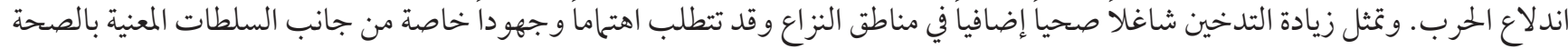
العمومية.

الاستتاجات: تمثل زيادة معدلات التدخين شاغلاً صحياً إضافياً في مناطق النزاع وقد تتطلب اهتماًً وجهوداً خاصةً من جانب السلطات المعنية بالصحة العامة.

\section{References}

1. WHO global report on trends in prevalence of tobacco smoking 2015. Geneva: World Health Organization; 2015 (http://apps.who. int/iris/handle/10665/156262, accessed 30 October 2017).

2. Maziak W, Hammal F, Rastam S, Asfar T, Eissenberg T, Bachir ME, et al. Characteristics of cigarette smoking and quitting among university students in Syria. Prev Med. 2004 Aug;39(2):330-6. PMID:15226042

3. Almerie MQ, Matar HE, Salam M, Morad A, Abdulaal M, Koudsi A, et al. Cigarettes and waterpipe smoking among medical students in Syria: a cross-sectional study. Int J Tuberc Lung Dis. 2008 Sep;12(9):1085-91. PMID:18713509

4. Barnard A. Syria weighs its tactics as pillars of its economy continue to crumble. New York Times. 13 July 2013 (http://www. nytimes.com/2013/07/14/world/middleeast/government-in-syria-searches-for-answers-as-economy-crumbles.html, accessed 30 October 2017).

5. Ozmichli, S. Report shows impact of war on Syrian economy. Al-Monitor. 4 February 2013 (https://www.al-monitor.com/pulse/ business/2013/02/economic-impact-syrian-crisis.html, accessed 30 October 2017).

6. Alienation and violence. Impact of Syria crisis report 2014. Damascus: Syrian Centre for Policy Research; 2015 (https://www. unrwa.org/sites/default/files/alienation_and_violence_impact_of_the_syria_crisis_in_2014_eng.pdf, accessed 30 October 2017).

7. Hisso, M. The poor get poorer in Syria. Al-Akhbar English. 10 August 2013 (http://english.al-akhbar.com/node/16688, accessed 30 October 2017). 
8. UNHCR Global appeal 2015 update - Syrian Arab Republic. Geneva: United Nations High Commissioner for Refugees; 2015 (http://www.unhcr.org/afr/publications/fundraising/5461e60716/unhcr-global-appeal-2015-update-syrian-arab-republic.html, accessed 30 October 2017).

9. Global status report on noncommunicable diseases 2014. Geneva: World Health Organization; 2014 (http://www.who.int/nmh/ publications/ncd-status-report-2014/en/, accessed 30 October 2017).

10. Islam SM, Purnat TD, Phuong NT, Mwingira U, Schacht K, Fröschl G. Non-communicable diseases (NCDs) in developing countries: a symposium report. Global Health. 2014 Dec 11;10:81.

11. Agaku IT, King BA, Dube SR; Centers for Disease Control and Prevention (CDC). Current cigarette smoking among adults United States, 2005-2012. MMWR Morb Mortal Wkly Rep. 2014 Jan 17;63(2):29-34. PMID:24430098

12. The tobacco epidemic: a global public health emergency. Tobacco use. Geneva: World Health Organization; 1998 (http://www. nzdl.org/gsdlmod?e=d-ooooo-oo---off-ocdl--00-0----0-10-0---0---odirect-10---4------0-11--11-en-50---20-about---00-0-1-00-0--4----0-011-10-outfZz-8-0o\&cl=CL1.242\&d=HASHo1e85b11bc1d8e14e8dc644c.2\&gt=1, accessed 30 October 2017).

13. Parkin DM, Pisani P, Lopez AD, Masuyer E. At least one in seven cases of cancer is caused by smoking. Global estimates for 1985 . Int J Cancer. 1994 Nov 15;59(4):494-504. PMID:7960219

14. Jradi H, Wewers ME, Pirie PR, Binkley PF, Ferketich K. Cigarette and waterpipe smoking associated knowledge and behaviour among medical students in Lebanon. East Mediterr Health J. 2013 Oct;19(10):861-8. PMID:24313150

15. Haddad LG, Malak MZ. Smoking habits and attitudes towards smoking among university students in Jordan. Int J Nurs Stud. 2002 Nov;39(8):793-802. PMID:12379297

16. Jarallah JS, al-Rubeaan KA, al-Nuaim AR, al-Ruhaily AA, Kalantan KA. Prevalence and determinants of smoking in three regions of Saudi Arabia. Tob Control. 1999 Spring;8(1):53-6. PMID:10465816

17. Syria bans smoking in public places. Framework Convention Alliance for Tobacco Control; 2010 (http://www.fctc.org/fca-news/ secondhand-smoke/380-syria-bans-smoking-in-public-places10, accessed 30 October 2017).

18. WHO report on the global tobacco epidemic 2013. Enforcing bans on tobacco advertising, promotion and sponsorship. Geneva: World Health Organization; 2013 (http://www.who.int/tobacco/global_report/2013/en/). 